\title{
Assessment of Groundwater Quality Using Water Quality Index in and Around Korba City, Chhattisgarh, India
}

\author{
Laxmi Prasad Chourasia \\ Department of Applied Geology, Doctor Harising Gour Vishwavidyalaya University, Sagar, India \\ Email address: \\ 1pc55@rediffmail.com \\ To cite this article: \\ Laxmi Prasad Chourasia. Assessment of Groundwater Quality Using Water Quality Index in and Around Korba City, Chhattisgarh, India. \\ American Journal of Software Engineering and Applications. Vol. 7, No. 1, 2018, pp. 15-21. doi: 10.11648/j.ajsea.20180701.12
}

Received: September 15, 2017; Accepted: May 4, 2018; Published: May 22, 2018

\begin{abstract}
The Korba city witnessed a sudden spurt in industrial activity with the establishment of Industrial complex. It is the industrial nucleus of Chhattisgarh state. The mixture of different kinds of untreated/ partially treated/ treated industrial wastes is being discharged through a number of drai passing in and around the Korba city. Further, the surface run off caused by rainfall also contribute to the groundwater pollution. In the present investigation, assessment of groundwater quality of drinking water sources in and around city of Korba has been carried out by using Water Quality Index (WQI). The groundwater quality data of pre and post monsoon seasons of the year 2013 and 2014 has been used for the calculation of water quality index. Fifteen parameters (TDS, $\mathrm{HCO}_{3}{ }^{1-}, \mathrm{SO}_{4}{ }^{2-}, \mathrm{Cl}^{1-}, \mathrm{NO}_{3}{ }^{1-}, \mathrm{Pb}, \mathrm{Ca}, \mathrm{Mg}, \mathrm{Na}, \mathrm{K}, \mathrm{Fe}, \mathrm{Mn}, \mathrm{Ni}, \mathrm{Cr}$ and $\mathrm{Cd}$ ) have been used to calculate the water quality index and each of the 15 parameters has been assigned a relative weight according to its relative importance in the overall quality of groundwater for drinking purpose. It was revealed that quality is not observed to improve in most of the locations after monsoon season period during the year 2013 but during the year 2014, the quality of groundwater is improved in post monsoon season in most of the samples.
\end{abstract}

Keywords: Assessment, Groundwater Quality, Korba, Water Quality Index, Chhattisgarh

\section{Introduction}

Groundwater is one of the most important resources as it is being used for different purposes such as drinking, irrigation and industrial. Its quality is mostly affected by the anthropogenic activities. The problem of groundwater pollution is aggravated due to municipal, industrial, agricultural and other miscellaneous sources and causes. Urbanization and industrialization are important factor, for the increasing demand of groundwater, at the same time they are responsible for the degradation/pollution of groundwater.

Water Quality Index (WQI) is a means to summarize large amount of water quality data into simple terms. It tells us whether the overall quality of water bodies poses a potential threat to various uses of water. Water quality index is a technique of rating that provides the composite influence of individual water quality on the overall quality of water for human consumption. It is a water quality indicator.

This technique is recently used by various research workers such as [2, 8, 12-17, 19, 23, 24, 26, 27] etc.

In the present paper assessment of groundwater quality in and around Korba city, Chhattisgarh, India has been carried out by applying WQI in the year 2013 and 2014 (Pre and Post monsoon) of groundwater. In the study area, thermal plants, industries and mining activities have been found to be engaged in the manufacturing, production and processing of various products. Most of them use various inorganic and organic chemicals as raw materials. The industrial effluents are discharged from effluent storage ponds to minor irrigation lakes which have become effluent settlement lakes. These activities degrade/pollute the groundwater.

The study area around Korba comprises about 550 square kilometer and located in the Chhattisgarh region. It falls in Survey of India toposheet nos. $64 \mathrm{~J} / 11$ and $64 \mathrm{~J} / 15$ on the scale of 1:50,000 and situated between $82^{\circ} 28^{\prime}-82^{\circ} 50^{\prime} \mathrm{N}$ latitudes and $22^{\circ} 18^{\prime}$ to $22^{\circ} 29^{\prime} \mathrm{E}$ longitude (Figure 1). The minimum ground elevation is about 280 meters and maximum 616 meter with reference to M. S. L. The area of investigation comprises the number of thermal plants, aluminium industries and coal mines. The area has good climatic conditions and is characterized by a hot dry summer and about 1500 millimeters annual average rainfall. The 
temperature reaches a maximum of around $48^{\circ} \mathrm{C}$ in the hot season and a minimum of around $5^{\circ} \mathrm{C}$ in the winter season.

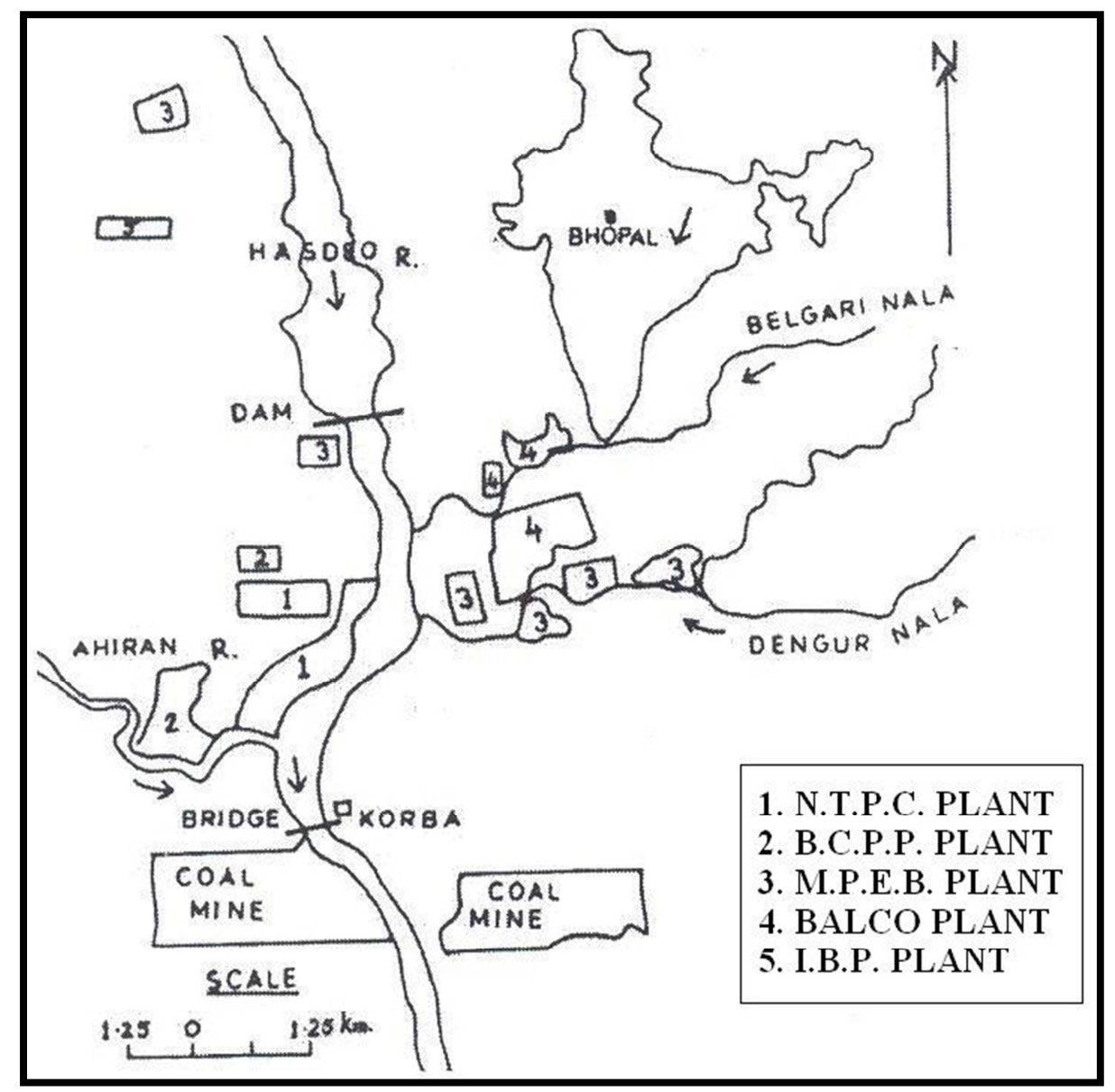

Figure 1. Location map of study area with plants and industries.

The geology of the area is studied by $[5,11,20]$. Most of the area is underlain by the gneissic granites and crystalline metamorphic rocks intruded by pegmatitic veins. It is overlain by the upper carboniferous rocks of Talchir formation followed by lower Permain rocks of Barakar formation. Talchir formation consists of green shales, siltstone and sandstone. The Barakar formation consists of medium to coarse grained, massive to thickly bedded, grayish white and compact sandstone. Major portion of Korba area is characterized by a number of coal seams, which are known as Korba Coal fields, and has an east-west strike.

The wells sampled during the study are situated in the above three lithologic formations. The granites and gneisses have very low porosity and permeability, come to together to produce high porosity and low permeability silty sandy clays. The Talchir and Barakar formations have medium to high porosity and permeability. 3-5 meters diameter dug well and $15 \mathrm{~cm}$ to $30 \mathrm{~cm}$ diameter tube wells are used for domestic and industrial purposes. Groundwater occurs under unconfined and semi-confined conditions. Water levels in dug wells during May-June, 2014 were ranged from 8-10 m below the ground level.

\section{Methodology}

In order to evaluate the groundwater chemistry, 20 groundwater samples from dug wells were collected during Oct-Nov. 2013 and May-June 2014. Sample locations are shown in Figure 2. For the measurements of the physpicochemical characteristics of water, the procedures described by $[1,9,21]$, were followed in the field and laboratory. In situ measurements ( $\mathrm{pH}, \mathrm{EC})$ were made in order to identify the chemical characters of the water and to evaluate their quality. The chloride, nitrate and sulphate were analyzed by chromatography and bicarbonate was determined by volumetric analysis. The calcium, magnesium, sodium and potassium were measured with the same instrument used for the anion analysis. The heavy metals were analyzed in a graphite furnace by an Absorption spectrophotometer. The average values of Chemical constituents of groundwater are given in Table 1 Major and minor constituents are plotted in the trilinear piper diagram (Figure 3). 


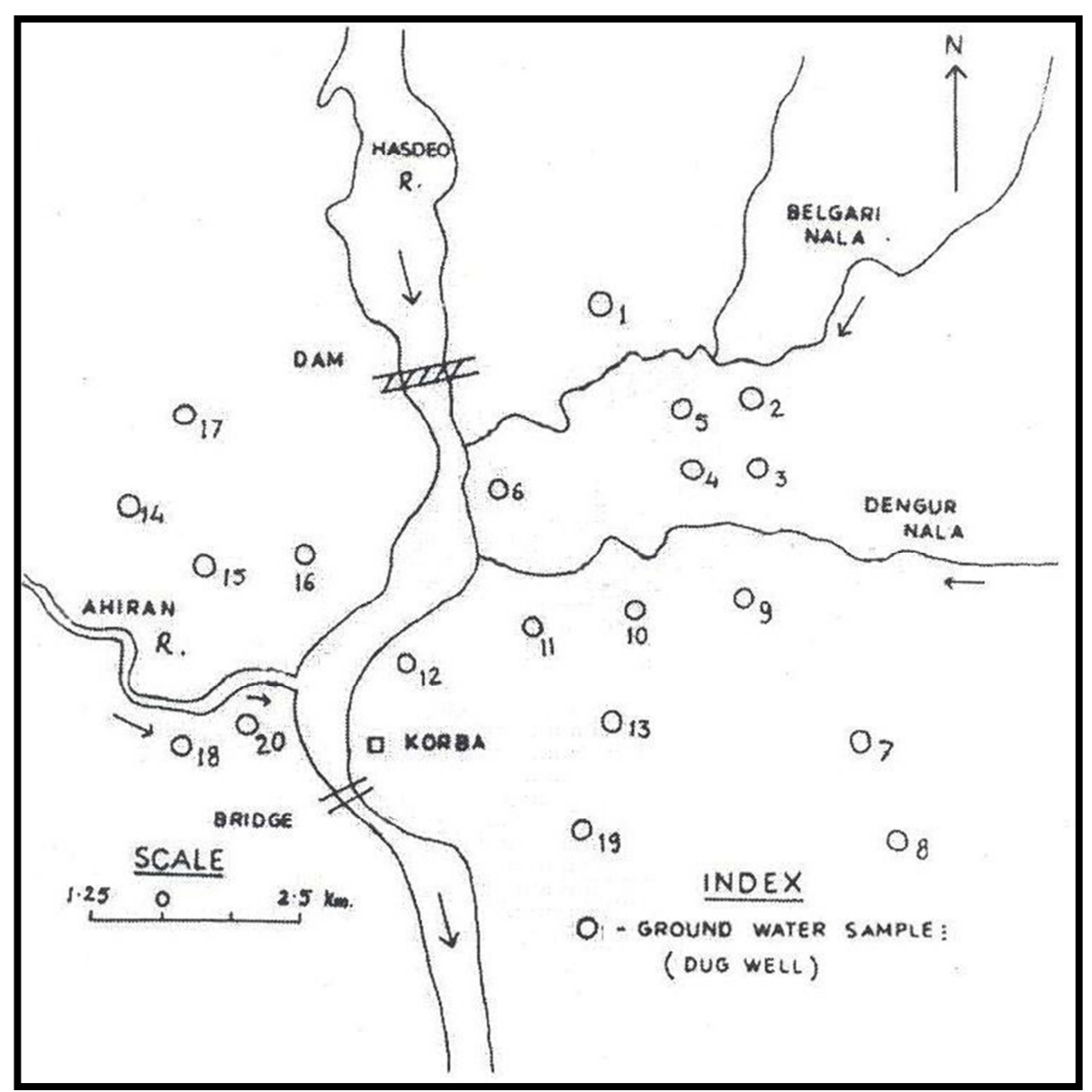

Figure 2. Location map of water sampling station.

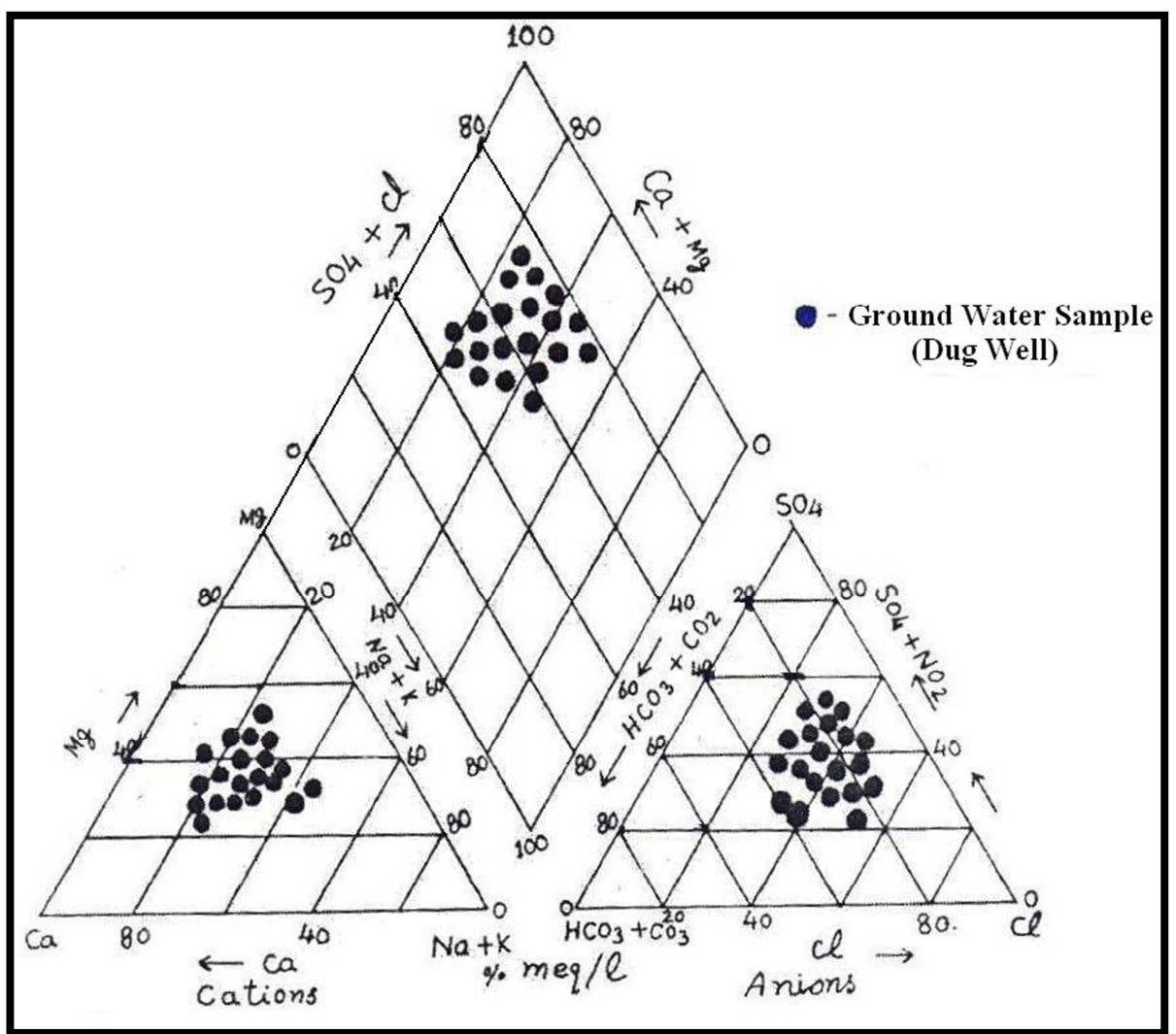

Figure 3. Piper diagram showing chemical composition of ground water. 
Table 1. Average values of the chemical constituents of Groundwater in $\mathrm{mg} / \mathrm{l}$.

\begin{tabular}{llll}
\hline S. No & Constituents & Oct.-Nov. 2013 (Post monsoon) & May-June 2014 (Pre monsoon) \\
\hline 1. & pH & 8.585 & 8.65 \\
2. & EC at $25^{\circ} \mathrm{C}($ us $/ \mathrm{cm})$ & 1515.3 & 1700.66 \\
3. & TDS & 905.09 & 1088.30 \\
4. & Hardness & 565.75 & 637.66 \\
5. & Calcium & 205.00 & 245.00 \\
6. & Magnesium & 75.08 & 83.01 \\
7. & Sodium & 30.05 & 44.10 \\
8. & Potassium & 20.00 & 25.81 \\
9. & Bicarbonate & 455.73 & 560.61 \\
10. & Chloride & 159.37 & 241.50 \\
11. & Sulphate & 266.83 & 384.20 \\
12. & Nitrate & 47.95 & 52.05 \\
13. & Cadmium & 0.03 & 0.08 \\
14. & Chromium & 0.06 & 0.07 \\
15. & Iron & 0.43 & 0.52 \\
16. & Manganese & 0.09 & 0.11 \\
17. & Nickel & 0.07 & 0.17 \\
18. & Lead & 0.02 & 0.03 \\
\hline
\end{tabular}

\section{Results and Discussion}

Chemical analysis of groundwater of the study area is divided into two categories, fresh water and saline water with regard to $\mathrm{pH}$, electrical conductivity, total dissolved solids and hardness. The fresh waters according to [18], are characterized as follows: Fresh (approximately-186-420 $\mathrm{mg} / \mathrm{L}$, total dissolved solids, neutral (approximately $\mathrm{pH} 7$ ), and soft (approximately $155-430 \mathrm{mg} / \mathrm{L}$, hardness as $\mathrm{CaCO}_{3}$; Calcium (approximately 44-144 $\mathrm{mg} / \mathrm{L}$ ), sulphate (approximately 8-100 $\mathrm{mg} / \mathrm{L}$ ) and have small concentration of $\mathrm{Na}$ (approximately $5-10 \mathrm{mg} / \mathrm{L}$ ). These waters are of the calcium-bicarbonate $\left(\mathrm{Ca}-\mathrm{HCO}_{3}\right)$ type, which results from the rocks of the study area. The saline waters are characterised which has hardness as $\mathrm{CaCO}_{3}$ approximately $1000-1400 \mathrm{mg} / \mathrm{l}$, contain Calcium (approximately 100-360 mg/L), sulphate (approximately 5-40 mg/L) and Chloride (approximately $1500-1700 \mathrm{mg} / \mathrm{L}$ ). The saline waters are of the calciumsulfate type which emerges from the underlying rocks of the study area. The saline waters form $50 \%$ of all waters of poor quality not suitable for human consumption.

The relative amount of ion concentration in all the water samples are namely $\mathrm{Ca}^{2+}>\mathrm{Mg}^{2+}>\mathrm{Na}^{1+}>\mathrm{K}^{1+}$ and $\mathrm{SO}_{4}{ }^{2+}>\mathrm{HCO}_{3}{ }^{1-}>\mathrm{Cl}^{1-}$. Sulphate concentration is high in numerous water samples, in contrast to samples which contain little sulphate in which $\mathrm{CO}_{2}$ is added to the water at the recharge area or along its underground path followed by its interaction with carbonate rocks. Magnesium could originate as well from the interaction of $\mathrm{CO}_{2}$ with evaporates associated with gypsum or anhydrite. Chloride and sodium occur in low concentrations. These low concentrations imply that practically no $\mathrm{NaCl}$ has been added underground to the water, not even to the mineralized water end member. Solution rates and concentrations are controlled primarily by the amount of water containing these minerals and to a lesser extent by the mode in which water is supplied, such as laminar or turbulent flows or impacting rain drops [17].

Major ions in the groundwater present a definite spatial trend. The chloride concentration ranges from 17.10-124.7 $\mathrm{mg} / \mathrm{L}$. The sulphate concentrations range from 24.4-715.7 $\mathrm{mg} / \mathrm{L}$. The maximum and minimum values of bicarbonate are 658.5 and $122.0 \mathrm{mg} / \mathrm{L}$, respectively. The calcium and magnesium concentrations are 44.1-380.5 $\mathrm{mg} / \mathrm{L}$ and 10.9$134.5 \mathrm{mg} / \mathrm{L}$, respectively. The maximum and minimum concentrations of sodium are 73.9-3.2 mg/L respectively while the potassium are 7.6-0.8 respectively. Nitrate values range from 16.5-56.3 mg/L, and the average being $47.95 \mathrm{mg} / \mathrm{L}$. In some samples, the nitrate concentration exceeds the permissible limit for drinking water as suggested by [28]. In general, the values in some of the samples are higher than those normally expected in non-polluted groundwater. The electrical conductivity at $25^{\circ} \mathrm{C}$ ranges from $310-2200 \mu \mathrm{s} / \mathrm{cm}$. The maximum and minimum values for total dissolved solids are 1408 and $186 \mathrm{mg} / \mathrm{L}$, respectively and the average is 905.09 $\mathrm{mg} / \mathrm{l}$. The average $\mathrm{pH}$ is 8.55 ; the maximum is 9.0 and the minimum 7.5. The concentration of heavy metals $(\mathrm{Cd}, \mathrm{Cr}, \mathrm{Fe}$, $\mathrm{Mn}, \mathrm{Ni}$ ) in some of the ground water samples are slightly higher the national and international guidelines of water for human consumption. The higher concentration of these metal is due to the discharge of industrial and domestic effluents of Korba Industrial complex in the streams and ponds which percolates downwards and pollutes the groundwater [25].

The geoenvironmental conditions of the study area have a profound effect on the mechanism of groundwater pollution. The disposal of waste effluents on land causes metal corrosion, leaching and ultimately adsorption of waste constituents on the soil particles, all of which results in persistent environmental problems. The groundwater has higher total hardness and alkalinity, as manifest in the increase in concentration of calcium, magnesium and bicarbonate. Sodium and chloride are associated with culturally related runoff or waste sources (Hem, 1985; Craig and Anderson (1979). According to [3] in general, the hydrogeochemical facies present in the area can be classified as sodium-chloride, sodium-bicarbonate, calciumchloride, calcium-bicarbonate, magnesium-chloride and magnesium-bicarbonate types, in which the sodium chloride and sodium-bicarbonate is the dominant 
hydrochemical facies. It is observed that downward leakage is greatest beneath the Kobra city and Industrial complex where the abstraction of groundwater is maximum and the shallow groundwater beneath the city is polluted. The coincidence of maximum leakage with the area where shallow groundwater is most polluted has serious implication for the future water supply in the deeper aquifer.

Water quality index is a good criteria to determine suitability of groundwater for drinking purpose. For the calculation of WQI, the relative weight for chemical parameters have been considered as given by [4]. Three steps have been followed for computing WQI. In the first step, each of the 15 parameters (TDS, $\mathrm{HCO}_{3}{ }^{1-}, \mathrm{Cl}^{1-}$, $\mathrm{SO}_{4}{ }^{2-}, \mathrm{NO}_{3}{ }^{1-}, \mathrm{Ca}^{2+} \mathrm{Mg}^{2+}, \mathrm{Na}^{1-}, \mathrm{K}^{1+}, \mathrm{Pb}, \mathrm{Fe}, \mathrm{Mn}, \mathrm{Ni}, \mathrm{Cr}$ and $\left.\mathrm{Cd}\right)$ have been assigned a weight (wi) according to its relative importance in the overall quality of water for drinking purpose. The maximum weight of 5 has been assigned to the parameters like nitrate, total dissolved solids, chloride, lead, sulphate and other metals due to their significant importance in water quality assessment $[12,13,17,22,26]$. Bicarbonate is given the minimum weight of 1 as it does not play any significant role in the water quality assessment. The parameters like calcium, magnesium, sodium, and potassium were assigned weight between 1 and 5 depending on this importance in the water quality assessment. In the second step, the relative weight (Wi) is computed form the following equation -

$$
\mathrm{W}_{\mathrm{i}}=\mathrm{w}_{\mathrm{i}} / \sum_{\mathrm{i}=1}^{\mathrm{n}} \mathrm{w}_{\mathrm{i}}
$$

Where $\mathrm{W}_{\mathrm{i}}$ is the relative weight, $\mathrm{w}_{\mathrm{i}}$ is the weight of each parameter and $\mathrm{n}$ is the number of parameter. The calculated relative weight $\left(\mathrm{W}_{\mathrm{i}}\right)$ of each parameter is given in table 2 .

In the third step, a quality rating scale $\left(\mathrm{q}_{\mathrm{i}}\right)$ for each parameters is assigned by dividing its concentration in each water sample by its respective standard according to the guidelines laid down by [4] and the results multiplied by 100 . The following formula is used -

$$
\mathrm{q}_{\mathrm{i}}=\left(\frac{\mathrm{C}_{\mathrm{i}}}{\mathrm{S}_{\mathrm{i}}}\right) \times 100
$$

Where $\mathrm{q}_{\mathrm{i}}$ is the quality rating, $\mathrm{C}_{\mathrm{i}}$ is the concentration of each chemical parameter in each water sample $(\mathrm{mg} / \mathrm{L}) . \mathrm{S}_{\mathrm{i}}$ is the Indian drinking water standard for each chemical parameter $(\mathrm{mg} / \mathrm{L})$ according to the guidelines of the [4].

For computing the WQI, the SIi is first determined for each chemical parameter which is then used to determine the WQI as per the following equation-

$$
\begin{gathered}
\mathrm{SI}_{\mathrm{i}}=\mathrm{W}_{\mathrm{i}} \times \mathrm{q}_{\mathrm{i}} \\
\mathrm{WQI}=\sum_{\mathrm{i}=1}^{\mathrm{n}} \times \mathrm{SI}_{\mathrm{i}}
\end{gathered}
$$

Where $\mathrm{SI}_{\mathrm{i}}$ is the sub index of the $\mathrm{i}^{\text {th }}$ parameter, $\mathrm{q}_{\mathrm{i}}$ is the quality rating based on concentration of $i^{\text {th }}$ parameter and $n$ is the number of parameters.

The water quality types can be determined on the basis of WQI. The types of water for drinking purpose can be classified according to WQI is as follows (Table 2)

Table 2. Relative weights (Wi) of Chemical parameter*.

\begin{tabular}{lllll}
\hline S. No. & Chemical parameter & Indian standard BIS (2012) & Weight $\left(\mathbf{w}_{\mathbf{i}}\right)$ & Relative Weight $\left(\mathbf{W}_{\mathbf{i}}\right)$ \\
\hline 1. & Total dissolved solid & 500 & 5 & 0.073 \\
2. & Bicarbonate & 245 & 1 & 0.014 \\
3. & Chloride & 250 & 5 & 0.073 \\
4. & Sulphate & 200 & 5 & 0.735 \\
5. & Nitrate & 45 & 5 & 0.735 \\
6. & Calcium & 75 & 3 & 0.044 \\
7. & Magnesium & 30 & 3 & 0.044 \\
8. & Sodium & 200 & 4 & 0.058 \\
9. & Potassium & 10 & 2 & 0.029 \\
10. & Iron & 0.3 & 5 & 0.073 \\
11. & Manganese & 0.1 & 5 & 0.073 \\
12. & Nickel & 0.02 & 5 & 0.073 \\
13. & Chromium & 0.05 & 5 & 0.073 \\
14. & Cadmium & 0.003 & 5 & 0.073 \\
15. & Lead & 0.01 & 5 & 0.073 \\
\hline
\end{tabular}

*All chemical parameters are in $\mathrm{mg} / \mathrm{l}$.

Table 3. Types of water for drinking purpose.

\begin{tabular}{ll}
\hline WQI Range & Type of Water \\
\hline$<50$ & Excellent water \\
$50-100$ & Good water \\
$100-200$ & Poor water \\
$200-300$ & Very poor water \\
$>300$ & Unsuitable \\
\hline
\end{tabular}

Water quality indices of groundwater of the study area are determined according to the WQI and their range and type of groundwater are given in Table 4 for pre and post monsoon periods. It was observed that quality of groundwater is same in about $50 \%$ samples of monsoon season. It reveals that the quality was not observed to improve in post monsoon season during the year 2013 but between the year 2014, the quality of groundwater was preserved to improve in post monsoon season in most of the samples. It is due to possibility of mixing of different kinds of industrial effluents/waste 
discharged by different industries operating in this area.

Table 4. Water Quality Indices of groundwater for Drinking purpose.

\begin{tabular}{|c|c|c|c|c|}
\hline Sample No. & WQI & Type of water Post-monsoon 2013 & WQI & Type of water Pre-monsoon 2014 \\
\hline 1 & 26.31 & Excellent water & 88.18 & Good water \\
\hline 2 & 117.62 & Poor water & 209.01 & Very poor water \\
\hline 3 & 110.48 & Poor water & 197.76 & Poor water \\
\hline 4 & 135.05 & Poor water & 150.08 & Poor water \\
\hline 5 & 216.74 & Very Poor water & 293.74 & Very poor water \\
\hline 6 & 226.66 & Very Poor water & 334.46 & Unsuitable water \\
\hline 7 & 51.29 & Good water & 99.35 & Good water \\
\hline 9 & 104.27 & Poor water & 212.32 & Very poor water \\
\hline 10 & 142.09 & Poor water & 251.15 & Very poor water \\
\hline 11 & 181.84 & Poor water & 184.41 & Poor water \\
\hline 12 & 197.76 & Poor water & 218.77 & Very poor water \\
\hline 13 & 85.26 & Good water & 91.61 & Good water \\
\hline 14 & 64.32 & Good water & 122.54 & Poor water \\
\hline 15 & 97.46 & Good water & 102.60 & Poor water \\
\hline 17 & 82.00 & Good water & 135.35 & Poor water \\
\hline 18 & 226.66 & Very poor water & 334.46 & Unsuitable water \\
\hline 19 & 61.68 & Good water & 87.56 & Good water \\
\hline 20 & 150.08 & Poor water & 234.58 & Very poor water \\
\hline
\end{tabular}

\section{Conclusion}

Water Quality Index is an excellent tool to classify the water quality of different water sources. It is a means to summarize large amounts of water quality data into simple terms for reporting the quality of water in a consistent manner. The significant degradation in the quality of groundwater in the area is indicated by the high concentration of sodium, calcium, chlorite and bicarbonate in groundwater samples of dug wells in the vicinity of effluent disposal sites. Temporal variations in the quality of groundwater and surface water in shallow aquifer are due to dilution followed by the seasonal rainfall.

\section{Acknowledgements}

The author wishes to thank Professor A. K. Shandilya, Head, Department of Applied Geology, Dr. H. S. Gour Vishwavidyalaya, Sagar M. P., India for providing necessary facilities to carry out this work.

\section{References}

[1] ف̀ APHA (Clesceri L. S., Greenberg A. E., Trussel R. R." Standard Methods for tire Examination of Water and Wastewater", APHA, Washington DC., 1995.

[2] Avvannavar, S. M. and Shrihari, S., "Evaluation of water qualify index for drinking purposes for river Netravahi, Mangalore, South India". Environ. Monit. Assess. 143: 279-29, 2008.

[3] Back, W Hydrochemical facies and groundwater flow pattern in northern part of Atlantic coastal plain. USGS Prof. paper $498-A$., 1966.
[4] Bureau of Indian Standers BIS, "Indian Standard Drinking Water Specification (Second Revision)", IS: 10500:2012, Bureau of Indian Standards, New Delhi., 2012.

[5] Blanford, W. T. Coal at Korba in the Bilaspur district. Report Geol. Surv. India III, 1870.

[6] Craig, E. and Anderson, M. P. The effect of urbanization on groundwater quality: a case study. Groundwater,v. 17, pp. 456-462., 1979

[7] Ford, D. C. and William, P. W. Karst Geomorphology and Hydrology, Unwinhyman, London, 1989, p, 601.

[8] Godbole, M. T. and Patode, H. S. Study of trace elements in groundwater in and around Hingoli Region, Maharashtra, India. Amer. Inter. Jour. Res. Formal and Applied and Natural Sci. PP. 151-155., 2014.

[9] Hem, J. D. Study and interpretation of chemical characteristics of natural water, U. S. Geol. Surv., water supply paper no. 1473, U. S. Government Printing Office, Washington, D. C., 1970.

[10] Hem, J. D. Study and interpretation of Chemical characteristics of natural water U.S. Geol. Surv. water supply paper no. 2254, U. S. Government Printing Office, Washington, D. C., 1985.

[11] Jain, J. K. and Chourasia, L. P. Impact of Industrial effluent on water Quality in Korba and Environ., Chhattisgarh, India. In proceeding International Conference on Environmental Management pp. 266-273, 2005.

[12] Jhariya, D. C., Kumar Tarun; Dewangan, Rakesh; Dharam Pal, Dewangan; Pankaj Kumar; Assessment of Groundwater Quality Index for drinking purpose in the Durg Distruct, Chhattisgarh using Geographical Information System (GIS) and Multi-criteria Decision Analysis (MCDA) Techniques. Jour. Geol. Soc. India, V. 89 (4) PP. 453-459., (2017).

[13] Kumar, P. J. S., and James, E. J (2015) Development of water quality Index WQI model for the groundwater in Tirupur district, South India. Chinese Jour. Geochem. V. 323, PP. 261269 doic 10. 100017/S/11631. 013. 0631-5. 
[14] Mangukiya, R, Bhattacharya, T. and Chakraborty, S., "Quality characterization of groundwater using water quality index in Surat city, Gujarat, India", International Research Journal of Environment Sciences. 1 (4): 14-23., 2012.

[15] Mahto, Mukes Kumar, Singh Prasoon Kumar and Tiwari, Ashwani Kumar; Hydrogeochemical evaluation of Groundwater quality and seasonal variation in East Bokaro Coal field region, Jharkhand, Jou. Geol. Soc. of India, V. 88 (2), PP. 160-173., 2016.

[16] Mishra, P. C. and Patel, R. K, "Study of the pollution load in the drinking water of Rairangpur, a small tribal dominated town of North Orissa", Indian J. Environmental and Ecoplanning. 5 (2): 293-298., 2001.

[17] Nagaraju, A. Sunil Kumar, K and Thejaswi, A. Assessment of Groundwater quality for Irrigation - A case study from Bandalamottu lead mining area, Guntur Distric, Andhra Pradesh, South India. Applied Water Science V. 4, PP. 385396, 2016.

[18] Ozler, Murat. M., Water balance and Water Quality in the Curijksu basin, Western Turkey. Hydrogeology Journal V. 7, No. 4, pp. 405-418., 1999.

[19] Patil, P. R. and Patil, B. T., "Evaluation of water quality index for drinking purposes for groundwater in and around Amalner Town (Maharashtra) ", International Journal of Chemical Sciences. 8(4): 2454-2460., 2010.

[20] Raja Rao, C.; Coalfields of Madhya Pradesh. Misc. Pub. of Geol. Surv. India, 1983.

[21] Rodier, J. Anailisis de has Aaquos (Techniques for water Chemical analysis) Omega, Barcelona, 1989.
[22] Srinivasamoorthy; K, Chidambaram, M., Prasanna, M. V., Vasanthavigar, M., John Peter. A. and Anandhan, P., "Identification of major sources controlling Groundwater Chemistry from a hard rock terrain - A case study from Mettur taluk. Salem district, Tamilnadu, India”, J. Earth System Sciences, 117(1): 49-58., 2008.

[23] Subba Rao, N.; Sludies on the water quality index in hard rock terrain of Gunter district, Andhra Pradesh, India. National Seminar on Hydrology of Precambrian Terrains and hard rock areas, pp. 129-134., 1997.

[24] Tiwari, Ashwini Kumar and Singh Abhay Kumar;Hydrogeochemical investigation and groundwater quality assessment of Pratapgarh district, Uttar Pradesh. Jour. Geol. Soc. of India, v. 83 (8), PP. 329-343., 2014.

[25] Travainen, T. Lahermo, P. Mannio, J Source of heavy metals in streams and headwater lakes in finland, water. Air Soil Pollu. 94-1, 1997.

[26] Vasanthavigar, M. Srinivasamoorthy, K, Vijayaragavan. K. Rajiv Ganthi, R., Chidambaram, S., Anandhan, P., Manivannan, R. and Vasudevan, S. "Application of water quality index for groundwater quality assessment: Thirumanimuttar sub-basin, Tamilnadu, India", Environ. Monit. Assess. 171(1-4):, 2010, pp. 595-609.

[27] Wazari, N. M. Environmental Geochemistry of soils and stream sediments from the Birmin-Gwari Artisanal gold mining area, North Wester Nigeria, University, Jour. Geosic. V. 2 (1), PP. 18-27., 2014.

[28] World Health Organization, Guidelines for drinking water quality. $2^{\text {nd }}$ Edn. Addendum to vol. 1: Recommendation, WHO, Geneva. 2011 